\title{
The occurrence of keratinophilic fungi in selected soils of Ladakh (India)
}

\author{
Sunil K. Deshmukh* ${ }^{* 1}$, Shilpa A. Verekar ${ }^{1}$, Archana Shrivastav ${ }^{2}$ \\ ${ }^{1}$ Department of Natural Products, Piramal Life Sciences Limited, 1, Nirlon Complex, Off Western Express Highway, Near NSE \\ Complex, Goregaon (East), Mumbai India \\ ${ }^{2}$ Department of Microbiology, College of Life Sciences, Cancer Hospital and Research Institute, Gwalior, India; *Corresponding \\ author: sunil.deshmukh@piramal.com
}

Received 24 July 2010; revised 27 August 2010; accepted 30 August 2010.

\begin{abstract}
138 soil samples were collected from various loca-tions in Ladakh, a cold desert in the Himalayan region, India and the samples were screened for the presence of keratinophilic fungi using the hair baiting techniques. 58 isolates were recovered and identified. The cultures were identified based on their macro- and micro-morphological features. A total of six genera and fourteen species were isolated namely Amauroascus kuehnii $(0.72 \%)$, Aphanoascus keratinophilus (4.34\%), Aphanoascus terreus (2.17\%), Auxarthron alboluteum (0.72\%), Auxarthron conjugatum (0.72\%), Chrysosporium articulatum (0.72\%), Chrysosporium mephiticum $(0.72 \%)$, Chrysosporium minutisporosum $(2.17 \%)$, Chrysosporium siglerae (0.72\%), Chrysosporium sp. (1.44\%), Chrysosporium tropicum (15.94 \%), Chrysosporium submersum (3.62\%), Chrysosporium state of Ctenomyces serratus (6.52\%) and Geomyces pannorum (1.45\%). The present study shows that keratinophilic fungi exist in the cold desert of Ladakh.
\end{abstract}

Keywords: Cold Desert; Ladakh; Soil Fungi;

Keratinophilic Fungi; India

\section{INTRODUCTION}

Ladakh, an interesting land deep within the folds of the Karakoram mountain ranges, is also known as the "land of passes" (La means pass and dakh means land). Ladakh is bordered by the Karakoram chain of mountains in the north and the Himalayas in the south. In Ladakh, altitude ranges from about $2750 \mathrm{~m}$ at Kargil to $7672 \mathrm{~m}$ at Saser Kangri in the Karakoram. The temperature vacillates between $27^{\circ} \mathrm{C}$ in summer to $-45^{\circ} \mathrm{C}$ in winter. Ladakh is situated between latitudes $30^{\circ} \mathrm{N}-36^{\circ} \mathrm{N}$ and longitudes $76^{\circ} \mathrm{E}-79^{\circ} \mathrm{E}$. The great Himalayan range lying to the south forms a barrier to monsoon in this area due to which Ladakh is an isolated cold desert region. Due to longer winters, the agriculture season is short with very little vegetation providing wind breaks as cover and so, totally exposed to the elements (e.g. wind, snow, rain, river, valley etc.), it experiences high velocity dust storms and snow blizzards. The region of Ladakh normally remains land locked between October to June because of snow and severe cold winter.

The climate and geographic diversity of Ladakh make it a potential interesting area to study the distribution of keratinophilic fungi. The objective of this study was to report the occurrence of keratinophilic fungi from selected soil habitats from various locations in Ladakh.

\section{MATERIALS AND METHODS}

One hundred and thirty eight soil samples were collected during June-July 2004 and June-July 2005. Sample collection was done only once in a year, as for most of the year the land is covered with snow. The samples were collected randomly from the superficial layer (depth not exceeding 3-5 cm) with the help of plastic spoon in sterilized polythene bags from various areas of Ladakh in the state of Jammu and Kashmir, India (Table 1). During the collection, attention was paid to the soils of uncultivated area, cultivated area, Pasture, road side, glacier bank, river banks and Pangong Tso. The soils are shallow and immature containing large portion of mineral grains. The soils are sandy with porous gravel and devoid of humus. The $\mathrm{pH}$ of soil ranges from 6.5 to 8.5. The collected samples were kept at $15^{\circ} \mathrm{C}$ for maximum of two weeks, if not processed immediately.

Keratinophilic fungi were isolated by the hair baiting technique of Vanbreuseghem [1] using human hair 
Table 1. Distribution of soil samples collected in Ladakh (India).

\begin{tabular}{ccccc}
\hline Sites & Altitude (m) & $\begin{array}{c}\text { No. of samples } \\
\text { Examined }\end{array}$ & $\begin{array}{c}\text { No. of samples } \\
\text { Positive }\end{array}$ & \% Positive \\
\hline Pangong Tso & 4350 & 29 & 7 & 24.13 \\
Chang La & 5289 & 8 & 2 & 25.00 \\
Durbuk & 4100 & 7 & 2 & 28.57 \\
Khardung La & 5602 & 45 & 11 & 24.44 \\
Tangste & 4100 & 3 & 1 & 33.33 \\
Lukung & 4345 & 6 & 2 & 33.33 \\
Nimmu & 3154 & 18 & 14 & 77.77 \\
Magnetic Hill & 4267 & 5 & 3 & 60.00 \\
Phey & 3150 & 3 & 3 & 100.00 \\
Leh & 3505 & 9 & 8 & 88.88 \\
Indus river & 3505 & 5 & 5 & 100.00 \\
Total & & $\mathbf{1 3 8}$ & $\mathbf{5 8}$ & $\mathbf{4 2 . 0 2}$ \\
\hline
\end{tabular}

as keratin bait. For this, sterile Petri dishes half filled with the soil samples and moistened with sterile tap water were baited by burying sterile human hairs in the soil. These dishes were incubated at room temperature and examined daily from the fifth day for fungal growth over a period of 4 weeks. After observing the growth under a stereoscopic binocular microscope, isolates were cultured on Sabouraud's dextrose agar supplemented with chloramphenicol (50 $\mathrm{mg} / \mathrm{l})$ and cycloheximide $(500 \mathrm{mg} / \mathrm{l})$. These fungi were identified based on the monographs of Sigler and Carmichael [2], Oorchschot [3], Currah [4], von Arx [5], Cano and Guarro [6], Vidal et al. [7], Sigler et al. [8], Sigler, Guarro and Punsola, [9] Cano and Guarro, [10] using macro and micro-morphological features of these cultures.

\section{RESULTS AND DISCUSSIONS}

Table1 indicates the occurrence of keratinophilic fungi in the cold desert of Ladakh. The maximum number of positive samples i.e. $42.02 \%$ was recorded from 138 soils. Out of soil samples collected $60.00 \%$, $77.77 \%, 29.62 \%, 70.58 \%, 100 \%, 21.42 \%$ and $20.00 \%$ samples are from uncultivated land, cultivated land, pastures, road side, Indus river bank, Pangong Tso and glacier banks respectively, were found positive for the presence of keratinophilic fungi.

The results of the isolations are presented in Table 2. They reveal that out of 138 samples only 58 yielded keratinophilic fungi. All 58 isolates were categorized in 14 species of six genera namely Amauroascus kuehnii (0.72\%), Aphanoascus keratinophilus (4.34\%), Aphanoascus terreus (2.17\%), Auxarthron alboleuteum (0.72\%), Auxarthron conjugatum $(0.72 \%)$, Chrysosporium articulatum $(0.72 \%)$, Chrysosporium mephiticum (0.72\%), Chrysosporium minutisporosum (2.17\%), Chrysosporium siglerae
(0.72\%), Chrysosporium sp. (1.44\%), Chrysosporium tropicum (15.94\%), Chrysosporium submersum (3.62\%), Chrysosporium state of Ctenomyces serratus $(6.52 \%)$ and Geomyces pannorum $(1.45 \%)$.

Chrysosporium tropicum was $15.94 \%$ in distribution and was the most dominant species. It is a cosmopolitan species of Chrysosporium and has been reported from various parts of India [11-13]. Chrysosporium state of Ctenomyces serratus, $6.52 \%$ was the next most frequently isolated species. It was reported from Indian soils by various workers $[14,15]$. It is interesting to note that Chrysosporium state of Ctenomyces serratus was mostly isolated from cultivated soils. Aphanoascus keratinophilus, $4.34 \%$, was the next most frequently isolated species followed by Chrysosporium submersum, 3.62\%. Aphanoascus keratinophilus was reported from various parts of India $[11,16,17]$. In this study, Chrysosporium submersum is reported for the first time from Indian soils. It was previously reported from river sediments in Catalonia and from soil and dust samples collected from Belgium [7]. In present study it is isolated from the cultivated soils only.

The other fungi isolated were Chrysosporium articulatum $(0.72 \%)$, Chrysosporium siglerae $(0.72 \%)$, Chrysosporium mephiticum (0.72\%), Chrysosporium minutisporosum $(2.17 \%)$ and Aphanoascus terreus $(2.17 \%)$. Aphanoascus terreus was reported from India's plains by various workers and dominates the mycobiota of Indian soils because it is adapted to warmer conditions of India $[11,13,18]$. But the percentage of occurrence of $A$. terreus is reported to be much less in hilly areas of Jammu and Kashmir as compared to Indian plain $[11,19]$, which confirms our findings. Various species of Chrysosporium have been reported from Indian soils $[11,18,20]$. Chrysosporium articulatum is reported for the first time from India. Chrysosporium mephiticum was reported from Indian 
Table 2. Occurrence of keratinophilic fungi from cold desert of Ladakh ( India).

\begin{tabular}{|c|c|c|c|c|c|c|c|c|c|c|c|c|c|c|c|c|}
\hline \multirow[t]{2}{*}{ Source of soil samples } & \multicolumn{3}{|c|}{ Khardung La } & \multirow{2}{*}{$\begin{array}{c}\text { Chang } \\
\text { La }\end{array}$} & \multicolumn{2}{|c|}{ Pangong Tso } & \multirow{2}{*}{$\begin{array}{c}\begin{array}{c}\text { Magnetic } \\
\text { hills }\end{array} \\
\text { Unculti- } \\
\text { e vated soil }\end{array}$} & \multirow{2}{*}{$\begin{array}{c}\text { Nimmu } \\
\text { Cultivated } \\
\text { soil }\end{array}$} & \multirow{2}{*}{$\begin{array}{c}\begin{array}{c}\text { Indus } \\
\text { river }\end{array} \\
\text { River } \\
\text { bank }\end{array}$} & \multirow{2}{*}{$\begin{array}{c}\text { Leh } \\
\begin{array}{c}\text { Road } \\
\text { side }\end{array}\end{array}$} & \multirow{2}{*}{$\begin{array}{l}\text { Lukung } \\
\text { Pastures }\end{array}$} & \multirow{2}{*}{$\begin{array}{c}\text { Phey } \\
\text { Pastures }\end{array}$} & \multirow{2}{*}{$\begin{array}{c}\begin{array}{c}\text { Tang- } \\
\text { ste }\end{array} \\
\text { Road } \\
\text { Side }\end{array}$} & \multirow{2}{*}{$\begin{array}{l}\text { Durbuk } \\
\text { Pastures }\end{array}$} & \multirow[t]{2}{*}{ Total } & \multirow[t]{2}{*}{$\begin{array}{c}\% \\
\text { Distribution }\end{array}$} \\
\hline & Pastures & $\begin{array}{l}\text { Gla- } \\
\text { cier }\end{array}$ & $\begin{array}{c}\text { Road } \\
\text { side }\end{array}$ & & $\begin{array}{l}\text { Pas- } \\
\text { tures }\end{array}$ & $\begin{array}{l}\text { Bank } \\
\text { of lake }\end{array}$ & & & & & & & & & & \\
\hline $\begin{array}{l}\text { No.of samples } \\
\text { examined }\end{array}$ & 23 & 17 & 5 & 8 & 15 & 14 & 5 & 18 & 5 & 9 & 6 & 3 & 3 & 7 & 138 & \\
\hline $\begin{array}{l}\text { No. of samples } \\
\text { positive }\end{array}$ & 5 & 3 & 3 & 2 & 4 & 3 & 3 & 14 & 5 & 8 & 2 & 3 & 1 & 2 & 58 & \\
\hline Distribution ( \% ) & 21.73 & 17.64 & 60.00 & 25.00 & 26.66 & 21.42 & 60.00 & 77.77 & 100.00 & 88.88 & 33.33 & 100.00 & 33.33 & 28.57 & 42.02 & \\
\hline \multicolumn{17}{|l|}{ Fungi recorded } \\
\hline Amauroascus kuehnii & - & - & - & - & - & - & - & - & - & 1 & - & - & - & - & 1 & 0.72 \\
\hline $\begin{array}{c}\text { Aphanoascus kerati- } \\
\text { nophilus }\end{array}$ & 3 & - & - & - & - & 1 & - & 2 & - & - & - & - & - & - & 6 & 4.34 \\
\hline Aphanoascus terreus & - & - & 1 & - & - & 1 & - & - & - & 1 & - & - & - & - & 3 & 2.173 \\
\hline $\begin{array}{c}\text { Auxarthron albolu- } \\
\text { teum }\end{array}$ & - & - & - & 1 & - & - & - & - & - & - & - & - & - & - & 1 & 0.72 \\
\hline $\begin{array}{c}\text { Auxarthron conjuga- } \\
\text { tum }\end{array}$ & - & - & - & - & - & 1 & - & - & - & - & - & - & - & - & 1 & 0.72 \\
\hline $\begin{array}{l}\text { Chrysosporium } \\
\text { articulatum }\end{array}$ & - & - & - & - & - & - & - & - & - & - & - & 1 & - & - & 1 & 0.72 \\
\hline $\begin{array}{l}\text { Chrysosporium } \\
\text { mephiticum }\end{array}$ & - & - & - & - & - & - & - & - & - & - & 1 & - & - & - & 1 & 0.72 \\
\hline $\begin{array}{l}\text { Chrysosporium } \\
\text { minutisporosum }\end{array}$ & - & - & - & - & - & - & 1 & 1 & - & - & 1 & - & - & - & 3 & 2.17 \\
\hline $\begin{array}{l}\text { Chrysosporium } \\
\text { siglerae }\end{array}$ & - & - & - & - & - & - & - & - & 1 & - & - & - & - & - & 1 & 0.72 \\
\hline Chrysosporium $\mathrm{sp}$. & - & 1 & 1 & - & - & - & - & - & - & - & - & - & - & - & 2 & 1.44 \\
\hline $\begin{array}{l}\text { Chrysosporium } \\
\text { tropicum }\end{array}$ & 1 & - & 1 & 1 & 4 & - & 1 & - & 4 & 6 & - & 1 & 1 & 2 & 22 & 15.94 \\
\hline $\begin{array}{l}\text { Chrysosporium } \\
\text { submersum }\end{array}$ & - & - & - & - & - & - & - & 5 & - & - & - & - & - & - & 5 & 3.62 \\
\hline $\begin{array}{c}\text { Chrysosporium state } \\
\text { of Ctenomyces } \\
\text { serratus }\end{array}$ & 1 & - & - & - & - & - & 1 & 6 & - & - & - & 1 & - & - & 9 & 6.52 \\
\hline Geomyces pannorum & - & 2 & - & - & - & - & - & - & - & - & - & - & - & - & 2 & 1.45 \\
\hline Total & 5 & 3 & 3 & 2 & 4 & 3 & 3 & 14 & 5 & 8 & 2 & 3 & 1 & 2 & 58 & \\
\hline
\end{tabular}

soils by Sigler et al. [9] and Deshmukh [21]. In the present study it is isolated from pasture soil of Lukung. Chrysosporium minutisporosum is also reported for the first time from Indian soils. Vidal et al. [7] recovered it for the first time from river sediments (Fluvia, Muga, Ter, and Ebre rivers), Catalonia, Spain. Labuda et al. [22] also recovered a single isolate from the soil and children's sandpit samples in city park of Nitra and Nová Baňa (Slovakia). In present study this fungi is isolated from soils of Lukung, Nimmu and Magnetic hills.

Auxarthron alboluteum and Amauroascus kuehnii were recovered from the soils of Chang La and Leh. Auxarthron alboluteum has been reported as Malbranchea albolutea from the soils of Utah [8] and Amauroascus kuehnii was previously reported from dung samples [4] and from soils of Lonar crater [23]. Auxarthron alboleuteum is reported for the first time from India. The genus Malbranchea and its anamorphs is common soil inhabitant and includes keratinophilic species which are potentially pathogenic to man and animals. Keratinolytic Malbranchea and its anamorphs have been reported from the other parts of Indian by various workers $[13,20,24,25]$.

Two isolates of unidentified species of Chrysosporium were recorded from the glacier bank soils and roadside soils of Khardung La and their systemic position is yet to be confirmed.

Geomyces pannorum was isolated from Khardung $\mathrm{La}(1.44 \%)$. It is a psychrophilic fungus found ubiquitously in temperate to Antarctic soils throughout the world [26,27]. It is also reported from other parts of India [28-30].

Auxarthron conjugatum was recorded from the soils of Pangong Tso. It was also recorded from Indian soils $[13,15,31]$ while surveying keratinophilic fungi. The other species isolated from Pangong Tso and its vicinity were Aphanoascus keratinophilus, A. terreus, and Chrysosporium tropicum. The fungi isolated from Pangong Tso shows their adaptation to such conditions where there is no visible vegetation. It also shows that these fungi are growing on the keratinic material added to the lake by birds, grazing and burrowing animals. In Ladakh, the higher altitude 
pastures are actually more productive. Local people appoint one or two members of the village to take all the animals to high pastures. While there, the animals graze the attendants spin wool, make butter and cheese and collect dung for the winter.

Chrysosporium tropicum, Aphanoascus keratinophilus, Geomyces pannorum and Chrysosporium state of Ctenomyces serratus were isolated from Khardung $\mathrm{La}$ and Auxarthron alboluteum, and C. tropicum from Chang La. Isolation of these fungi at $5602 \mathrm{~m}$ to 5289 $\mathrm{m}$ shows that these fungi can survive at this height and extremely low temperature (upto $-40^{\circ} \mathrm{C}$ ). These samples were collected from Military base at Chang $\mathrm{La}$ and Khardung $\mathrm{La}$, indicates that these fungi are associated with human activity.

Ladakh, is a part of the state of Jammu and Kashmir. Deshmukh [15] has reported Aphanoascus keratinophilus, C. tropicum, Chrysosporium state of Ctenomyces serratus, Geomyces pannorum, Malbranchea sp., Microsporum gypseum, $M$. nanum, $M$. vanbreuseghemii, Trichophyton ajelloi, T. terrestre and Uncinocarpus reesii from glacier banks of Kashmir (Srinagar, $1730 \mathrm{~m}$; Gulmarg, $2650 \mathrm{~m}$ and Sonmarg, $2730 \mathrm{~m}$ altitude). In the present study the fungi viz. $M$. gypseum, M. nanum, M. vanbreuseghemii, Trichophyton ajelloi, $T$. terrestre and $U$. reesii were altogether absent. Similarly while surveying the keratinophilic fungi from Indian soils, Garg [11] had isolated $\mathrm{Ar}$ throderma quadrifidum, Aphanoascus keratinophilus, A. terreus, Chrysosporium evolceanui, C. tropicum, Chrysosporium state of Ctenomyces serratus, Trichophyton ajelloi, T. mentagrophytes, Microsporum canis, $M$ cookie, and $M$. gypseum from soils of Srinagar, Kashmir (1730 m altitude) of which A. quadrifidum, $T$. ajelloi, T. mentagrophytes, $M$. canis, $M$ cookie and $M$. gypseum were altogether absent in the present survey. Deshmukh and Verekar [32], had isolated Aphanoascus keratinophilus, A. terreus, C. queenslandicum, C. tropicum, Chrysosporium sp., C. xerophilum, Chrysosporium state of Ctenomyces serratus, Malbranchea gypsea, Microsporum canis, Microsporum gypseum and Trichophyton mentagrophytes from the western Himalayan state of Himachal Pradesh $(800 \mathrm{~m}$ to $3500 \mathrm{~m}$ altitude) which is also adjacent to the state of Jammu and Kashmir of which C. queenslandicum, $C$. xerophilum, Mal. gypsea, M. canis, M. gypseum and $T$. mentagrophytes were altogether absent in this study. This may be due to harsh climate of cold desert or the samples being collected from high altitude of 3100 to $5600 \mathrm{~m}$ and the complexity of the ecosystem.

Keratinophilic fungi play a vital role in nature in the breaking down and mineralization of keratinous substrate into simpler substances. Their ability to grow on keratin regarded them as pathogens to human and animals including livestock. For example, an invasive infection was noted in an 18-year old woman who was a bone marrow transplant recipient as Chrysosporium, where the infection began as a facial swelling and extended into the central nervous system [33]. Chrysosporium zonatum was reported causing disseminated infection in a patient with chronic granulomatous disease [34]. In Japan, C. zonatum strains were also isolated from bronchial lavage from a female in Chiba and from a male in Kyushu. Both patients were with pulmonary cavities [35]. Gymnascella hyalinospora was isolated from invasive pulmonary infection in a patient with acute mycelogenous leukemia [36]. Steininger et al [37] report the case of brain abscesses by the Chrysosporium anamorph of Nannizziopsis vriesii in a 38-year-old, HIV-seropositive Nigerian man. Geomyces pannorum is also found as a causative agent of dermatomycosis and onychomycosis in humans [38,39]. Chrysosporium ophiodiicola was isolated from a subcutaneous granuloma of a snake (Elaphe obsolete obsoleta) [40]. The Chrysosporium anamorph of Nannizziopsis vriesii has been isolated from cases of dermatitis in tenacled snakes [41], brown tree snakes [42], chameleons [43], crocodiles [44], bearded dragons [45] and from a nasal granuloma in an Ameiva lizard [46]. In a recent report, a Chrysosporium species related to Nannizziopsis vriesii was isolated from a case of cutaneous hyalohyphomycosis from two green iguanas [47]. Vissiennon et al [48] reported disseminated mycotic alterations in skin, lungs and liver in male garter snake (Thamnophis) infected with Chrysosporium queenslandicum. Chrysosporium tropicum was reported from comb lesion in two different breeds of chicken in India [49]. Thus, these fungi may be regarded as "opportunistic" pathogens.

\section{CONCLUSIONS}

In conclusion, our study indicates that keratinophilic fungi exist in the cold desert of Ladakh. The difference in the prevalence of keratinophilic fungi in the soils of different parts of India may be attributed to their tolerance and adaptation to various biotic and abiotic factors such as ecological conditions, soil type, and vegetation. Garg [11] also emphasized that the climate and perhaps other environmental factors are apparently important in determining the distribution of keratinophilic fungi.

\section{ACKNOWLEDGEMENTS}

The authors are grateful to Dr. Somesh Sharma, MD, Piramal Life Sciences, Mumbai and Dr. B. R. Shrivastav, Director, Cancer Hospital 
and Research Institute, Gwalior for all kinds of support during the work.

\section{REFERENCES}

[1] Vanbreuseghem, R. (1952) Technique biologique pour 1' isolement des dermatophytes du sol. Annales de la Societe belge de medecine tropicale, 32, 173-178.

[2] Sigler, L. and Carmichael, J.W. (1976) Taxonomy of Malbranchea and some other hyphomycetes with arthroconidia. Mycotaxon, 4, 349-488.

[3] Oorschot van, C.A.N. (1980) A revision of Chrysosporium and allied genera. Studies in Mycology, 20, 1-89.

[4] Currah, R.S. (1985) Taxonomy of onygenales: Arthrodermaceae, gymnoascaceae, myxotrichaceae and onygenaceae. Mycotaxon, 24, 1-216.

[5] von Arx, J.A. (1986) The ascomycetes genus Gymnoascus. Persoonia, 13, 173-183

[6] Cano, J. and Guarro, J. (1990) "The genus Aphanoascus. Mycological Research, 94, 355-377.

[7] Vidal, P., Valmaseda, M., Vinuesa, M.Á and Guarro, J. (2002) Two new species of Chrysosporium. Studies in Mycology, 47, 199-209.

[8] Sigler, L., Hambleton, S., Flis, A.L. and Paré, J. (2002) Auxarthron teleomorphs for Malbranchea filamentosa and Malbranchea albolutea and relationships within Auxarthron. Studies in Mycology, 47, 111-122.

[9] Sigler, L., Guarro, J. and Punsola, L. (1986) New keratinophilic species of Chrysosporium. Canadian Journal of Botany, 64, 1212-1215.

[10] Cano, J. and Guarro, J. (1994) Studies on keratinophilic fungi. III. Chrysosporium siglerae sp. nov. Mycotaxon, 51, 75-79.

[11] Garg, A.K. (1966) Isolation of dermatophytes and other keratinophilic fungi from soils in India. Sabouraudia 4 , 1966, 259-264.

[12] Nigam, N. and Kushwaha, R.K.S. (1989) Some new reports on keratinophilic fungi. Current Science, 58, 1374.

[13] Singh, C.J., Geetha-Singh, B. and Singh, B.S. (1994) Keratinophilic fungi of Ghana birds Sanctuary Bharatpur (Rajasthan). Advances in Plant Sciences, 7, 280-291.

[14] Padhye, A.A., Pawar, V.H., Sukapure, R.S. and Thirumalachar, M.J. (1967) Keratinophilic fungi from marine soils of Bombay India Part I. Hindustan Antibiotics Bulletin, 10, 138-141.

[15] Deshmukh, S.K. (2002) Incidence of dermatophytes and other keratinophilic fungi in the glacier bank soils of Kashmir (India). Mycologist, 16, 165-167.

[16] Anbu, P., Hilda, A. and Gopinath, S.C. (2004) Keratinophilic fungi of poultry farm and feather dumping soil in Tamil Nadu, India. Mycopathologia, 158, 303-309.

[17] Vidyasagar, G.M., Hosmani, N. and Shivkumar, D. (2005) Keratinophilic fungi isolated from hospital dust and soils of public places at Gulbarga, India. Mycopathologia, 159, 13-21.

[18] Kushwaha, R.K.S. and Agarwal, S.C. (1976) Some keratinophilic fungi and related dermatophytes from soils. Proceedings Indian National Science Academy, 42, pp. 102-110.

[19] Deshmukh, S.K. and Agarwal, S.C. (2003) Isolation of
Dermatophytes and other keratinophilic fungi from soils of Jammu (India). Mycoses, 46, 226-228.

[20] Deshmukh, S.K. (2004) Isolation of Dermatophytes and other Keratinophilic fungi from the vicinity of salt pan soils of Mumbai (India). Mycopathologia, 157, 265-267.

[21] Deshmukh, S.K. (2002) Isolation of dermatophytes and other keratinophilic fungi from Karnala bird sanctuary, Maharashtra (India). Journal of Basic and Applied Mycology, 1, 194-196.

[22] Labuda, R., Nad'ová, L. and Vén, T. (2008) First record of Chrysosporium europae, Ch. fluviale and Ch. minutisporosum in Slovakia. Biologia, 63, 38-39.

[23] Deshmukh, S.K. and Verekar, S.A. (2006) Keratinophilic fungi from the vicinity of meteorite crater soils of Lonar (India). Mycopathologia, 162, 303-306.

[24] Orr, G. F. and Kuehn, H.H. (1972) Notes on Gymnoascaceae. II. Some Gymnoascaceae and keratinophilic fungi from Utah. Mycologia, 64, 55-72.

[25] Ajello, L. and Padhye, A.A. (1974) Keratinophilic fungi of the Galapagos Island. Mykosen, 17, 239-243.

[26] Caretta, G. and Piontelli, E. (1977) Microsporum magellanicum and Cunninghamella antarctica, new species isolated from Australia and Antarctic soil of Chile. Sabouraudia, 15, 1-10.

[27] Caretta, G. and Piontelli, E. (2004) Keratinophilous fungi from Antarctic terrestrial habitats. In: Kushawaha R.K.S. Eds., Scientific Publisher, Jodhpur, India, 29-38.

[28] Deshmukh, S.K., Agrawal, S.C. and Jain, P.C. (2000) Isolation of Dermatophytes and other keratinophilic fungi from soils of Mysore(India). Mycoses, 43, 55-57.

[29] Kaul, S. and Sumbali, G. (2002) Keratinophilic fungi from poultry farm soils of Jammu, India. Mycologist, 14, 89-91.

[30] Katiyar, S. and Kushwaha, R.K.S. (2001) Human hair colonizing fungi in water sediments of India. Mycopathologia, 152, 81-84.

[31] Jain, P.C. and Agrawal, S.C. (1979) Some addition to Indian Malbranchea. Kavaka, 7, 69-72.

[32] Deshmukh, S.K. and Verekar, S.A. (2006) The Occurrence of Dermatophytes and other keratinophilic fungi from the soils of Himachal Pradesh (India). Czech Mycology, 58, 117-124.

[33] Warwick, A., Ferrieri, P., Burke, B. and Blazar, B.R. (1991) Presumptive invasive Chrysosporium infection in bone marrow transplant recipient. Bone Marrow Transplant, 8, 319-322.

[34] Roilides, E., Sigler, L., Bibashi, E., Katsifa, H., Flaris, N. and Panteliadis, C. (1999) Disseminated infection due to Chrysosporium zonatum in a patient with Chronic granulomatous disease and review of non-Aspergillus fungal infection in patients with this disease. Journal of Clinical Microbiology, 37, 18-25.

[35] Sigler, L., Flis, A.L. and Carmichael, J.W. (1998) The genus Uncinocarpus (Onygenaceae) and its synonym Brunneospora: new concepts, combinations and connections to anamorphs in Chrysosporium, and further evidence of relationship with Coccidioides immitis. Canadian Journal of Botany, 76, 1624-1636.

[36] Iwen, P.C., Sigler, L., Tarantolo, S., Sutton, D.A., Rinaldi, M.G., P.Lackner, R., McCarthy, D.I. and Hinrichs, S.H. (2000) Pulmonary infection caused by Gymnascella hyalinospora in a patient with acute mycelogenous leukemia. 
Journal of Clinical Microbiology, 38, 375-381.

[37] Steininger, C., van Lunzen, J., Sobottka, I., Rohde, H., Horstkotte, M.A. and Stellbrink, H.J. (2005) Mycotic brain abscess caused by opportunistic reptile pathogen. Emerging Infectious Diseases, 11, 349-350.

[38] Zelenková, H. (2006) Geomyces pannorum as a possible causative agent of dermatomycosis and onychomycosis in two patients. Acta Dermatovenerol Croatica, 14, 21-25.

[39] Gianni, C., Caretta, G. and Romano, C. (2003) Skin infection due to Geomyces pannorum var. pannorum. Mycoses, 46, 430-432.

[40] Rajeev, S., Sutton, D.A., Wickes, B.L., Miller, D.L., Giri, D., Van Meter, M., Thompson, E.H., Rinaldi, M.G., Romanelli, A.M., Cano, J. and Guarro, J. (2009) Isolation and characterization of a new fungal species, Chrysosporium ophiodiicola, from a mycotic granuloma of a black rat snake (Elaphe obsolete obsoleta). Journal of Clinical Microbiology, 47, 1264-1268.

[41] Bertelsen, M.F., Crawshaw, G.J., Sigler, L. and Smith, D.A. (2005) Fatal cutaneous mycosis in tenacled snakes (Erpeton tentaculatum) caused by the Chrysosporium anamorph of Nannizziopsis vriesii. Journal of Zoo and Wildlife Medicine, 36, 82-87.

[42] Nichols, D.K., Weyant, R.S., Lamirande, E.W., Sigler, L. and Mason, R.T. (1999) Fatal mycotic dermatitis in captive brown tree snakes (Boiga irregularis). Journal of Zoo and Wildlife Medicine, 30, 111-118.

[43] Pare, J.A., Coyle, K.A., Sigler, L., Maas, A.K. and Mitchell, R.L. (2006) Pathogenicity of the Chrysosporium anamorph of Nannizziopsis vriesii for veiled cha- meleons (Chamaeleo calyptratus). Medical Mycology, 44, 25-31.

[44] Thomas, A.D., Sigler, L., Peucker, S., Norton, J.H. and Neilan, A. (2002) Chrysosporium anamorph of "Nannizziopsis vriesii associated with fatal cutaneous mycoses in the salt water crocodile (Crocodylus porosus). Medical Mycology, 40, 143-151.

[45] Bowman, M.R., Pare, J.A., Sigler, L., Naeser, J.P., Sladky, K.K., Hanley, C.S., Helmer, P., Phillips, L.A., Brower, A. and Porter, R. (2007) Deep fungal dermatitis in three inland bearded dragons (Pogona vitticeps) caused by the Chrysosporium anamorph of Nannizziopsis vriesii. Medical Mycology, 45, 371-376.

[46] Martell, A., Fonteyne, P.A., Chiers, K., Decostere, A. and Pasmans, F. (2006) Nasal Nannizziopsis vriesii granuloma in an Ameiva lizard (Ameiva chaitzami). Vlaams Diergeneeskd. Tijdschrift, 75, 30-307.

[47] Abarca, M.L., Martorell, J., Castella, G., Ramis, A. and Cabanes, F.J. (2008) Cutaneous hyalohyphomycosis caused by a Chrysosporium species related to Nannizziopsis vriesii in two green iguanas (Iguana iguana). Medical Mycology, 46, 349-354.

[48] Vissiennon, T., Schuppel, K.F., Ullrich, E. and Kuijpers, A.F. (1999) Case report, A disseminated infection due to Chrysosporium queenslandicum in a garter snake (Thamnophis). Mycoses, 42, 107-110.

[49] Saidi, S.A., Bhatt, S., Richard, J.L., Sikdhar, A. and Ghosh, G.R. (1994) Chrysosporium tropicum as a probable cause of mycoses of poultry in India. Mycopathologia, 125, 143-147. 